\title{
Culture and Trade in the European Union
}

Teresa L. Cyrus

Dalhousie University, Halifax, Canada

\begin{abstract}
Since its origin, the European Union has focused on removing barriers to the full integration of its members' economies. While formal institutions have been adapted, informal social norms may have also changed. In this paper, variables from the World Values Survey are used to estimate the cultural distance between countries to examine the extent to which cultural distance and bilateral trade are related. Cultural distance reflects the differences between two countries' norms and beliefs. It is predicted that cultural distance reduces trade while trade reduces cultural distance. Fixed-effects regressions for exports and cultural distance show that, contrary to the prediction, cultural distance raises trade and trade raises cultural distance. However, these results are questionable due to the potential problem of endogeneity. Once the problem of endogeneity is addressed with the use of simultaneous equations, the results show that, in fact, cultural distance has no effect on trade, while trade reduces cultural distance.
\end{abstract}

JEL Classifications: E02, F13, F15

Keywords: Trade, Culture, Gravity, European Union

\footnotetext{
* Corresponding Author: Teresa L. Cyrus; Department of Economics, Dalhousie University, Halifax, Nova Scotia, B3H 4R2, Canada; Tel: +1 9024946992, Fax: +1 9024946917, E-mail: tcyrus@dal.ca.
} 


\section{Introduction}

The history of the European Union (EU) is an ongoing story of removing barriers and promoting integration. From the removal of tariffs, promised by the Treaty of Rome and achieved by 1968, to the Single European Act guaranteeing a complete internal market, to Maastricht's goal of a common monetary policy, there has been a continual push towards increased integration. While the formal institutions and laws governing economic interactions have changed, however, the EU countries' underlying cultures - the norms and beliefs of their citizens - may have changed as well. Further, it is interesting to note to what extent trade in goods influenced this cultural change. This paper focuses on the relationship between culture and trade. This is a complex relationship since it is likely that the cultural differences between countries affect the trade that occurs between them, and that the goods involved in countries' trade lead to changes in culture. The direction of these links is not clear. It is possible that countries that are closer together in cultural terms may trade more since a similar culture gives individuals an advantage in terms of communication. It is also possible that if trade is based on comparative advantage, countries with different cultures may trade more. Likewise, trade may allow the flow of ideas, causing countries' cultures to become more similar, or it may cause nations to become more entrenched in their own cultural differences.

It is important first of all to define what is meant by the word culture. The terms culture, institutions, norms, social capital, and so on have become ubiquitous in the economics literature, and yet a clear definition of each term has not yet been agreed upon. Douglass North, in his 1993 Nobel Prize lecture, stated the following: "Institutions are the humanly devised constraints that structure human interaction. They are made up of formal constraints (rules, laws, constitutions), informal constraints (norms of behavior, conventions, and self-imposed codes of conduct), and their enforcement characteristics. Together they define the incentive structure of societies and economies." North's informal constraints (norms and codes of conduct) are what this paper considers as culture. White and Tadesse (2008) define culture as a "population's shared habits and traditions, learned beliefs and customs, attitudes, norms, and values" (p. 1,079). While the formal means of enforcing institutions (rules, laws, or constitutions) may change only

${ }^{1}$ http://nobelprize.org/nobel_prizes/economics/laureates/1993/north-lecture.html 
slowly and in discrete ways, the informal means (culture) may change more quickly; changes in culture, over time, lead to changes in formal institutions. Guiso et al. (2006) claim that culture remains "fairly unchanged from generation to generation" (p. 23). On the contrary, culture can indeed change; in particular, it may change when individuals in a country are exposed to other beliefs and values, which can occur through trade.

Gravity models explore the determinants of bilateral trade and include both pull and push factors to explain what helps or hinders the individuals in two countries when engaging in international trade. Melitz (2008), Guo (2004), and Hutchinson (2005) have shown that speaking a common language facilitates international trade transactions. If two countries share a colonizer, they may employ a common framework for interactions, as shown by Bastos and Silva (2008). A common language and a common colonizer are often included as dummy variables in gravity regressions and are usually thought to be stable over time. If a culture can change, however (changing more when countries are exposed to international trade), then it is important to consider the measures of culture that can change.

The World Values Survey (WVS), an international survey undertaken in almost 100 countries over the last 30 years, provides a way to measure changes in culture over time. The World Values Survey provides data for five waves of surveys: 1981 1984, 1989 1993, 1994 1998, 1999 2004, and 2005 2008, although not every country is surveyed in every wave. On average, 1,400 individuals are interviewed in each country, and the survey is nationally representative. The results collected over a 30-year time period may show a change in social norms.

Sociologists such as Inglehart and Welzel (2005), Inglehart and Baker (2000), and Inglehart et al. (2008) have used the WVS questionnaires to study happiness, democratization, and modernity. Economists, including Knack and Keefer (1997), La Porta et al. (1997), and Beugelsdijk (2006) have particularly focused on trust and how it affects per-capita GDP. Tabellini (2010) uses the WVS to measure the effect of culture on economic development in the regions of Europe, using regional data for eight countries. Other surveys have also been used to measure culture. Guiso et al. (2009) use the Eurobarometer surveys to examine how bilateral trust affects bilateral trade, but they include only 17 European countries. Disdier and Mayer (2007) also use Eurobarometer surveys, finding that the opinions of the EU15 citizens regarding new entrants have an effect on bilateral trade. Only the World Values Survey, however, provides data on all the European Union countries, as well as a large set of industrial and developing countries around the world. 
In this paper, the difference between countries' norms as a way of explaining the trade flowing between them is examined. Whether trade itself can help explain these cultural differences is also shown. As countries engage in trade, they discover the ideas, methods, and technologies that are embodied in the goods that they import. Such repeated exposure to foreign ideas may lead to changes in social norms. The Silk Route is a historical example of trade that enabled cultural change. As Chan (2007) puts it, "Learning useful foreign values is similar to acquiring useful foreign technologies" (p. 737), and he shows how openness leads to trust. Kónya (2006) states that "cultural costs differ from physical ones in that they can be eliminated by learning" (p. 494). Coyne and Williamson (2012) show how openness (measured by the share of exports and imports in GDP) affects a measure of culture derived from WVS questions, but they do not examine bilateral relationships.

Section II describes the empirical framework to be used in the regressions, and Section III identifies empirical issues to be addressed. Section IV presents the results. Finally, Section V concludes.

\section{Trade and Culture Relationship}

The goal of this paper is to determine how cultural differences affect bilateral trade and vice versa. It also studies how these relationships differ for European Union countries compared to the worldwide average. The World Values Survey (WVS) is used to construct a measure of the cultural distance between two countries.

\section{A. Measurement of cultural distance}

To measure cultural distance, I use the same four variables from the WVS that are used by Tabellini (2010) and Coyne and Williamson (2012) to construct their measures of culture: trust, respect, control, and obedience. Trust is the percentage of respondents who agree that most people can be trusted. Trust may affect trade because a high level of trust in others may reduce transaction costs, leading to a greater ability and willingness to engage in international transactions. Respect is the percentage of respondents who say 
that tolerance and respect for other people is a quality that is important for children to learn at home. If an individual has a high respect measure, the individual may be more willing to engage with those outside his/her immediate network. Control is the average response (from 1 to 100) that indicates how much freedom of choice and control in life respondents feel. Individuals who feel that they can control their lives are more likely to try to improve their own well-being. Obedience is the percentage of respondents who say that obedience is a quality that is important for children to learn at home. A society emphasizing this quality may be one that discourages risk-taking and pursues fewer outside transactions. Tables 1 to 4 show the trust, respect, control, and obedience measures for 27 European Union countries.

The four World Values Survey variables are merged into one cultural distance variable as follows. For each country, the average levels of trust, respect, control, and obedience are found. Overall cultural distance for countries $i$ and $j$ is then:

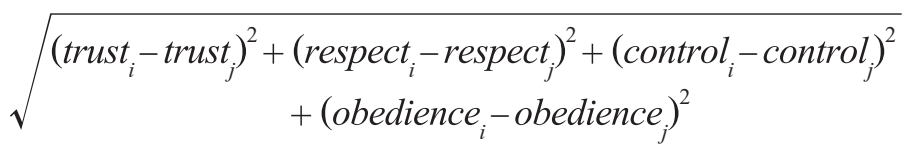

To illustrate, among the first 12 members of the European Union in the 2005 2008 period, the pair of countries that was most culturally near to each other was Germany and Italy, with a cultural distance score of 13.17, and the country-pair that was culturally farthest from each other was Germany and the UK, with a cultural distance of 32.58 . In the 2005 2008 wave of the WVS, trust had a value of 33.8 for Germany, 27.5 for Italy, and 30.0 for the UK; respect had a value of 75.1 in Germany, 74.4 in Italy, and 85.3 in the UK; control had a value of 68 in Germany, 63 in Italy, and 73 in the UK; and obedience had a value of 15.6 in Germany, 26.3 in Italy, and 46.2 in the UK. In the whole sample, Hong Kong in 2005 2008 was the most culturally distant from its trading partners, while Spain in 1981 1984 was culturally the nearest.

The relationship between cultural distance and trade is not obvious. It may be that cultural distance reduces trade because individuals have a more difficult time forming relationships or trusting in contracts when their norms or beliefs are different; on the other hand, if trade is based on comparative advantages, then greater differences between individuals will allow greater gains from trade. Similarly, the effect of trade on cultural distance could go in either direction: the exposure to outside ideas provided by trade may

\footnotetext{
${ }^{2}$ The numbers for the United Kingdom represent Great Britain only, as Northern Ireland was not surveyed in every period. Croatia is not included as an EU member in this study, as it was not a member at the time of the most recent World Values Survey.
} 
allow individuals to become closer over time in terms of their norms, or may cause them to become further entrenched in terms of their initial beliefs.

\section{B. The effect of cultural distance on trade}

The gravity model is used to establish the determinants of bilateral trade, focusing on whether cultural distance lowers or raises trade. Three versions of the gravity model are provided: a basic model that, in addition to cultural distance, includes only the GDP of the exporter, the GDP of the importer, and the distance between them; an augmented model that also includes standard gravity variables (GDP per capita, contiguity, and landlocked status); and, finally, a model that adds cultural and institutional variables, including dummies for common language and common colonizer and measures of religious and legal similarity. The full model is as follows:

$$
\begin{aligned}
& \ln \left(\text { Exports }_{i j}\right)=\beta_{0}+\beta_{1} \text { Cultural Distance }_{i j}+\beta_{2} \ln \left(G D P_{i}\right)+\beta_{3} \ln \left(G D P_{j}\right) \\
& +\beta_{4} \ln \left(\text { Distance }_{i j}\right)+\beta_{5} \ln (\text { GDP per capita })+\beta_{6} \ln \left(G D P \text { per capita }_{j}\right) \\
& +\beta_{7} \text { Common Border }_{i j}+\beta_{8} \text { Landlocked }_{i j}+\beta_{9} \text { Common Language }_{i j} \\
& +\beta_{10} \text { Common Colonizer }_{i j}+\beta_{11} \text { Religious Similarity }_{i j} \\
& +\beta_{12} \text { Legal Similarity }_{i j}+u_{i j}
\end{aligned}
$$

Here, Cultural Distance is $_{i j}$ as described. Exports Ex $_{i j}$ represents real exports from country $i$ to country $j$ (nominal exports in current US dollars divided by the US Consumer Price Index); GDP ${ }_{i}$ and $G D P_{j}$ is the gross domestic product of country $i$ and $j$, respectively, in constant 2000 US dollars; Distance $e_{i j}$ is the great-circle distance between the capital cities of countries $i$ and $j$; GDP per capita ${ }_{i}$ and GDP per capita are GDP $_{j}$ divided by population for countries $i$ and $j$, respectively; Common Border ${ }_{i j}$, Landlocked ${ }_{i j}$, Common Language $e_{i j}$, and Common Colonizer ${ }_{i j}$ are dummies indicating, respectively, whether the two countries share a border; whether either or both of the countries are landlocked (this is not a binary variable, but rather can take the values of 0,1 , or 2); whether they have a common language; and whether they share the same colonizer. Religious Similarity ${ }_{i j}$ is a variable created from data on religion from La Porta et al. (1999), who provided the percentage of a country's residents in 1980 and identified them as Catholic, Protestant, Muslim, or Other. This paper follows Guiso et al. (2009) in defining religious similarity as the probability that two randomly-selected individuals in the two 
countries will follow the same religion. This is calculated by multiplying together the percentage of individuals following a given religion in each country, and then summing over all religions (Catholic, Muslim, Protestant, and Other). Legal Similarity ${ }_{i j}$ uses data in La Porta et al. (1999) to create a dummy variable equal to 1 if both countries have the same legal origin (English, French, German, Scandinavian, or Socialist). My expectation is that an increase in cultural distance will reduce exports, and an increase in the GDP of either the exporting or importing country will raise exports. An increase in distance is expected to reduce exports. An increase in either country's level of development (GDP per capita) is expected to raise exports. All of the dummy variables, as well as both religious and legal similarities, are expected to have positive coefficients, representing increased trade, other than being landlocked, which is predicted to reduce exports.

The gravity variables that are most typically used to measure culture or institutionscommon language, common colonizer, religious similarity, and legal similarity — are each correlated with cultural distance, but only moderately. The correlation between cultural distance and common language is -0.02 , between cultural distance and common colonizer -0.12 , between cultural distance and religious similarity -0.22 , and between cultural distance and legal similarity -0.26 . Cultural distance, which focuses on norms and beliefs, therefore measures something different from these more standard gravity variables. In particular, cultural distance is more amenable to change, since norms and beliefs held by individual residents of a country are likely to be updated continuously, while the other variables are static; a country's colonizer and legal origin are fixed in history, after all. This dynamic aspect of cultural distance makes it an interesting variable to study. Since cultural distance can change, this factor can potentially add something useful to a gravity model.

Data on exports from each country to every other country in the world are made available by the IMF in its Direction of Trade Statistics. ${ }^{3}$ Data on GDP and population are taken from the World Bank's World Development Indicators. Distance is calculated using the great-circle method. ${ }^{4}$

As with the standard gravity variables, dummy variables representing EU membership are included to see whether belonging to the European Union raises or lowers the trade between a pair of countries, holding constant their GDPs, the distance between them, and so on. In the first set of regressions, a dummy variable (EU) that is

\footnotetext{
${ }^{3}$ Data prior to the year 2000 were graciously provided by Andrew K. Rose.

${ }^{4}$ The gravity dummy variables are obtained from Andy Rose (http://faculty.haas.berkeley.edu/arose/).
} 
equal to 1 if both trading partners are members of the EU, is included. Also included is a dummy representing common membership in any other trading bloc (other FTA). Since some members of the EU have belonged to it from the beginning, whereas others have joined more recently, the EU dummy is split up into three separate variables in the next set of regressions. A dummy variable (EUold) that is equal to 1 if both trading partners are among the first 12 members of the EU (i.e., had joined by 1986) is included; this set includes Belgium, Denmark, France, Germany, Greece, Ireland, Italy, Luxembourg, Netherlands, Portugal, Spain, and the United Kingdom. A dummy variable (EUnew) that is equal to 1 if both the exporter and the importer are among the latest 12 entrants to the EU at the time of the most recent WVS is also included. The list is composed of Bulgaria, Cyprus, the Czech Republic, Estonia, Hungary, Latvia, Lithuania, Malta, Poland, Romania, Slovakia, and Slovenia. The third and final dummy variable (EUoldnew) is equal to 1 if one of the trading partners is among the first 12 members of the EU and the other trader is among the most recent 12 entrants.

\section{The effect of trade on cultural distance}

After showing the effect of cultural distance on trade, next step is to see how trade affects cultural distance. My expectation is that cultural distance falls as trade increases. Of course, many other variables are likely to affect the cultural distance between two countries. Per capita GDP indicates a country's level of development, and the level of development is likely to affect culture. Geographical distance and sharing a border may affect cultural distance since geographical proximity provides individuals with more opportunities to interact. Speaking a common language facilitates communication and so it is likely to reduce cultural distance. Sharing a common colonizer is likely to reduce cultural distance since it implies sharing a set of common founding institutions. Countries that are more similar in terms of religion and with a common legal origin are likely to be less culturally distant.

The cultural distance model is thus:

Cultural Distance $_{i j}=\beta_{0}+\beta_{1} \ln \left(\right.$ Exports $\left._{i j}\right)+\beta_{2} \mid \ln ($ GDP per capita $)$

$-\ln ($ GDP per capita $) \mid+\beta_{3} \ln \left(\right.$ Distance $\left._{i j}\right)+\beta_{4}$ Common Border $_{i j}$

$+\beta_{5}$ Common Language $_{i j}+\beta_{6}$ Common Colonizer $_{i j}$

$+\beta_{7}$ Religious Similarity $_{i j}+\beta_{8}$ Legal Similarity $_{i j}+u_{i j}$ 
Here, Cultural Distance ${ }_{i j}$ and Exports $_{i j}$ are as defined earlier; $\mid \ln ($ GDP per capita $)$ $-\ln ($ GDP per capita $) \mid$ is the absolute value of the difference in log per-capita GDP of the two countries; and Distance $_{i j}$, Common Border ${ }_{i j}$, Common Language ${ }_{i j}$, Common Colonizer $_{i j}$, Religious Similarity $_{i j}$, and Legal Similarity ${ }_{i j}$ are as defined earlier.

This paper's expectations are that exports will reduce cultural distance; the difference in GDP per capita will raise cultural distance; geographical distance will raise cultural distance; sharing a border, speaking a common language, or sharing a common colonizer will reduce cultural distance; and religious or legal similarity will reduce cultural distance.

As in the trade equation, I again add dummies for EU membership (both countries in the EU; both countries among the first 12 members of the EU; both countries among the most recent 12 members of the EU; one country in the first 12 and one country in the most recent 12) and for common membership in another trade bloc.

EU membership has a correlation coefficient of -0.14 with cultural distance; EU countries are less culturally distant than other country-pairs in the sample. EU membership has a correlation coefficient of 0.20 with exports; EU countries trade more than other country-pairs in the sample. The regressions that will be run will show whether the high trade and low cultural distance between EU countries have a causal relationship or can be explained by the other variables in the gravity and cultural distance equations.

Summary statistics are presented in Table 5. Data sources are shown in Appendix 1, and the 90 countries included in the sample are listed in Appendix 2.

\section{Empirical Issues}

\section{A. Specification}

The gravity regressions, as is common in the literature, are estimated in log-linear form, with exports, GDP, GDP per capita, and distance entering in natural logarithms and with the dummy variables entering directly. Since the WVS is collected in five waves, only five years of trade data can be included. Including country-pair fixed effects would be optimal if this were a standard panel of yearly bilateral trade data, but this is 
not a balanced panel; the WVS does not visit every country in every wave of surveys, and so while trade data are available, the cultural distance variable is not available for every country-pair in every time period. Some countries are only surveyed once, in fact, and so country-pair fixed effects cannot be possibly estimated in this research. All regressions therefore include year fixed effects, exporter-year fixed effects, and importeryear fixed effects, but not country-pair fixed effects. This is not out of line with other recent papers; Guiso et al. (2009) use both exporter and importer fixed effects, while Francois and Manchin (2007) use only importer fixed effects.

\section{B. Cultural distance}

As stated above, cultural distance between two countries is measured as the square root of the sum of the squared differences between each country's trust, respect, control, and obedience measures. This formula is also used by Tadesse and White (2008), although they use other variables in their measure. Other measurement techniques are, of course, possible. De Groot et al. (2004) include a dummy variable that is equal to 0 if the difference between the country-pair's institutions exceeds a specified fraction of the sample standard deviation. Tabellini (2010) and Coyne and Williamson (2012) define culture as the sum of the trust, respect, and control variables, less the obedience variable; i.e., trust + respect + control - obedience, the idea being that trust, respect, and control encourage economic interactions, while obedience discourages such interactions. To measure cultural distance, one could then take the difference between two countries' culture variables. Another possibility, also used by Tabellini (2010), is to take the first principal component of the four variables included in the culture variable to create a new variable to measure culture. Again, one could take the difference between two countries' first principal components to create a cultural distance variable. I have performed both of the variations found in Tabellini (2010) and the results are similar to those presented here.

\section{Selection bias}

The log of real exports is used as the dependent variable in the gravity regressions and as an independent variable in the cultural distance regressions; if a country-pair has zero 
trade, that observation will therefore drop out of the regression. This truncation is not ideal, as the fact that two countries that do not trade is something that a trade regression should be able to explain. One method of addressing this problem, used by Santos Silva and Tenreyro (2006) and Westerlund and Wilhelmsson (2011), is to use a Poisson estimator for the gravity equation. The Poisson Pseudo Maximum Likelihood (PPML) estimator estimates the gravity model in its multiplicative form, and it is useful when a model cannot be log-linearized; that is, a gravity regression of trade on income and distance would take the form $E\left(T_{i j} \mid Y_{i}, Y_{j}, D_{i j}\right)=\beta_{0} Y_{1}^{\beta 1} Y_{2}^{\beta 2} D_{i j}^{\beta 3}$ rather than the conventional log-linear form $\ln \left(T_{i j}\right)=\ln \left(\beta_{0}\right)+\beta_{1} \ln \left(Y_{i}\right)+\beta_{2} \ln \left(Y_{j}\right)+\beta_{3} \ln \left(D_{i}\right)+u_{i j}$.

Another option is for researchers to use a two-step Heckman procedure to measure the likelihood that a country-pair will experience positive trade, and then include that likelihood ratio in the gravity regression. The first step of the Heckman procedure is a probit regression to determine the probability that a given country-pair will engage in trade at all. The inverse Mills ratio from this probit regression is then included as an explanatory variable in the second step of the procedure, which is an OLS regression of trade on the gravity variables. Linders and de Groot (2006) perform a Heckman sample selection correction and then note that omitting the instances of zero trade leads to satisfactory results (p. 15). Since only $2.4 \%$ of this paper's country-pairs (241 out of 9,910) experience zero trade, the Heckman correction does not lead to a different outcome. This paper shows an example for a simple gravity regression in Appendix 3, in which Columns 1 and 3 show very similar coefficients and significance levels for the variables.

\section{Endogeneity}

Since it is likely that cultural distance influences trade flows, and trade has an impact on cultural distance, causality may be difficult to establish and the coefficients in ordinary least squares regressions will be biased. For example, if an omitted variable simultaneously causes a country-pair's trade flows to be high and cultural distance to be low, then trade and cultural distance will be correlated even if there is no direct relationship between them.

\footnotetext{
${ }^{5}$ The correlation coefficient between exports and cultural distance is in fact -0.08 ; countries that have greater trade flows are more similar in terms of culture.
} 
One method for dealing with endogeneity is the use of instrumental variables. While many potential instruments were considered for such an exercise, none proved to pass the over-identifying restrictions test. Other authors, such as Coyne and Williamson (2012) and Disdier and Mayer (2007), commonly use a lag of the variable in question as its instrument. Unfortunately, such a technique is not possible in this case. Since the WVS is not completed for every country in every time period, lagged cultural distance is not available for a majority of country-pairs.

An alternative way of addressing the possible problem of endogeneity is by exploiting the timing of the WVS, which is conducted in waves over a three- to fiveyear period in each case. Because of this, cultural distance is calculated for the overall period rather than for a particular year; that is, this paper calculates cultural distance for the 1981 1984 period, the 1989 1993 period, the 1994 1998 period, the 1999 2004 period, and the 2005 2008 period, corresponding to the five waves of the WVS. While this paper has cultural distance data only for these time periods, there are trade data for every year. Trade data from the end of the period (i.e., 1984 for the 1981 1984 period, 1993 for the 1989 1993 period, and so on) are therefore used in the trade regressions, so that cultural distance is primarily determined before the trade takes place. Further, trade data are used from the beginning of the period (i.e., 1981 for the 1981 1984 period, and so on) in the cultural distance regressions, so that trade is primarily determined before cultural distance is measured. The independent variables in the regressions have therefore been realized before the dependent variables take place, thereby reducing the endogeneity bias. These regressions, discussed below, are presented in Tables $6 \sim 8$.

A third and more rigorous method of addressing the endogeneity issue is to employ a simultaneous equations strategy and estimate the effect of cultural distance on trade and the effect of trade on cultural distance simultaneously. In this method, three-stage least squares is used to estimate a system of structural equations. Exports and cultural distance are taken to be endogenous variables in this case, and the remaining variables are taken to be exogenous and are used as instruments for the endogenous variables. This method is utilized below in Table 9 and 10 . 


\section{Results}

\section{A. Determinants of trade: separate equations}

Tables 6 and 7 describe the determinants of trade. Table 6 includes dummy variables representing common membership in the EU or in another trade bloc, while Table 7 focuses on the oldest and newest members of the EU.

Column 1 of Table 6 presents a basic gravity regression, regressing exports on cultural distance, common membership in the EU or another bloc, the exporter's and importer's GDP, and distance. The gravity variables have the expected signs and are highly significant. The Other FTA dummy is positive and significant, but the EU dummy is, surprisingly, negative and highly significant as two countries trade less if they are in the EU than if they are not. Given that it is known the EU countries trade a great deal with each other, it must be that the other gravity variables are providing the explanation for trade within the EU. Cultural distance exerts a negative influence on trade and is significant at the $10 \%$ level. Countries that have different norms and beliefs thus find it more challenging to engage in trade.

Column 2 of Table 6 presents an augmented gravity model, adding GDP per capita, a common border dummy, and landlocked status. The cultural distance coefficient falls slightly, enough to make the variable insignificant. Column 3 adds cultural and institutional variables (common language, common colonizer, religious similarity, and legal similarity), all of which are correlated with cultural distance, so their inclusion is expected to affect the cultural distance coefficient, and it does: cultural distance is no longer negative, but turns positive and significant. Holding constant other measures of cultural differences, such as common language and common colonizer, cultural distance now raises exports rather than reducing them. If at least some trade is based on differences in endowments or tastes, then differences in norms and beliefs will reflect different comparative advantages, leading to higher trade.

Rather than amalgamating all EU countries together, Table 7 divides them into old and new members, adding three dummies: one that is equal to 1 when the two trading partners are both among the first 12 members of the EU, a second that is equal to 1 if the two trading partners are both among the most recent 12 members to join the EU, and a third that is equal to 1 if one trading partner is among the first 12 members of the EU and the other trading partner is among the 12 most recent members. Interestingly, it can 
be seen that the first 12 members trade less among themselves than would another pair of countries with the same gravity characteristics, while the new members trade more among themselves. Trade between an old and a new member of the EU is lower than trade between other country-pairs. The Other FTA dummy remains positive, but loses significance in Column 3. As in Table 6, cultural distance has a negative sign in the first two columns, but is positive and significant in Column 3 when other cultural and institutional variables are included. Cultural distance apparently raises trade. Similarly, as in Table 6, cultural distance raises trade once other measures of cultural differences are included, so at least some trade is based on differences between countries in their norms and beliefs.

\section{B. Determinants of cultural distance: separate equations}

Table 8 presents the determinants of cultural distance. Column 1 includes dummies representing membership in the EU and other trade blocs. The coefficient on exports is both highly significant and positive: holding all else constant, exports raise cultural distance. The control variables are all significant and most have the expected signs. Differences in GDP per capita are highly significant and have a positive coefficient; countries that are of similar levels of development are also more similar culturally. Geographical distance also has a positive and significant coefficient; countries that are closer to each other have more similar cultures, due possibly to the increased exposure that close proximity allows. Surprisingly, sharing a border increases cultural distance. The common language dummy has a negative and significant coefficient, so sharing a language reduces cultural distance. The common colonizer dummy is both negative and highly significant as being colonized by the same country reduces a country-pair's cultural distance, possibly because the colonizer imposes similar institutions. Religious similarity and common legal origin both have the expected negative sign and are significant at the $99 \%$ level. The EU dummy in Column 1 is positive. If both countries are part of the European Union, their cultural distance is higher, holding constant the other variables in the regression. For other FTA members, cultural distance is lower than otherwise. As to why exports would raise it distance, it is possibly because trade encourages countries to specialize in what they are best at producing, allowing inherent differences to become entrenched. 
Column 2 of Table 8 shows how trade affects cultural distance, with dummies representing trade between the first 12 EU members, between the newest $12 \mathrm{EU}$ members, and between the oldest 12 and newest 12, as well as a dummy representing other trade blocs. EUold and EUoldnew have positive coefficients, so cultural distance is higher for these country-pairs. For the newest 12 members, cultural distance is lower, however. The same is true for members of other trade blocs. The newest members of the EU therefore have more similar norms and beliefs than the countries that have been in the EU for much longer; despite all the efforts at integration, essential differences still remain at the level of the individual.

\section{Simultaneous equations}

Table 9 shows the results of a three-stage least squares simultaneous equations estimation that jointly examines the determinants of exports and cultural distance. This technique solves the potential problem of endogeneity bias and is therefore the preferred methodology. Column 1 presents the trade regression. For simplicity, only the complete gravity regression, with all cultural and institutional variables, is shown. Most of the coefficients are very similar in both size and significance to the results in Table 6, with a few exceptions: the coefficient on the importer's GDP is now half the size, the coefficient on the per-capita GDP of the exporter is now negative, and being landlocked now has a significant negative impact on trade. Most notably, the coefficient on cultural distance is now larger, but is insignificantly different from zero, so cultural distance does not help to explain bilateral exports. Column 2 shows the determinants of cultural distance. Compared to Column 1 of Table 8, the coefficient on membership in a nonEU trade bloc is now insignificant, and the effects of distance and a common colonizer are smaller than before. Strikingly, the effect of exports on cultural distance is now negative: trade reduces, not increases, the cultural distance between countries. This was the original expectation. The familiarity allowed by trade brings countries closer.

Table 10 shows the simultaneous equation results when dummy variables representing the oldest and newest EU members are included. The trade regression, presented in Column 1, shows a few changes from the results in Table 7: the coefficient on trade between an old and a new EU member is now insignificant. As shown in Table 9, the coefficient on the importer's GDP is now much smaller, the exporter's percapita GDP now has a negative impact on trade, and landlocked countries experience a 
significantly lower amount of trade. Also, as it can be seen in Table 9, cultural distance now has no effect on exports. Column 2 shows that the effect of being in a non-EU trade bloc is now insignificantly different from zero and, as in Table 9, some variables (distance, common colonizer, and legal similarity) have smaller effects than before. As illustrated in Table 9, exports now have a negative and significant impact on cultural distance.

The use of simultaneous equations to address the endogeneity problem has therefore provided a very different view of the relationship between trade and cultural distance. When estimated carefully, cultural distance is shown to have no impact on bilateral exports; the standard gravity variables, including cultural and institutional variables, explain trade. On the other hand, we now see that exports have a significant and negative effect on cultural distance. The difference between two countries' norms and beliefs shrinks when those countries engage in trade. The familiarity engendered by the establishment of trading relationships and the consumption of each other's goods allows the cultures of the traders to become more alike.

Since the simultaneous-equations strategy is the preferred one, it is worth discussing these results in more detail. In Column 1 of both Table 9 and Table 10, which shows the determinants of bilateral exports, the basic gravity variables of GDP and distance have the expected signs and are highly significant. The effect of geography, shown in the common border dummy and the landlocked variable, are also significant in explaining bilateral exports. The institutional variables that have been used in other studies, namely sharing a common colonizer and having a similar legal origin, are also highly significant. Religious similarity, which is a reflection of culture, is insignificant, while another measure of culture, common language, is strongly significant. Of course, common language is not just a measure of culture, but also a measure of transaction costs, and so its significance is not surprising. Cultural distance, like religious similarity, is insignificant in explaining trade. A possible interpretation of these results is that economic, geographic, and institutional variables are important in explaining bilateral exports, while cultural variables play little role in our understanding of trade flows.

Column 2 of Table 9 and Table 10 shows the determinants of bilateral cultural distance. Per-capita GDP differences raise cultural distance, as does geographic distance and sharing a common border. Variables representing cultural and institutional similarity, including common language, common colonizer, religious similarity, and legal similarity, reduce cultural distance. The coefficient on bilateral exports is negative and highly significant, indicating that trade acts to reduce the cultural differences between countries. 
EU members have higher trade and lower cultural distance than the average countrypair in the sample, but the coefficient on the EU dummy in Table 9 show that, holding all else constant, being in the EU results in lower trade and higher cultural distance. This surprising result implies that, given their GDPs, the distance between them, and their cultural and institutional similarities, the EU countries should trade even more than they do, and should have a lower cultural distance. On the other hand, when the oldest and newest members of the EU are considered separately in Table 10, it can be seen that the newest 12 members of the EU trade more than would be expected and have lower cultural distance. Most of these 12 countries had been Communist countries under the domination of the former Soviet Union, and so their culture and institutions evolved along similar lines.

\section{Conclusion}

This paper has explored the relationship between exports and cultural distance for 90 countries between 1981 and 2008, focusing on the European Union. There is a negative correlation between exports and cultural distance, but the relationship becomes more complex when control variables are added.

The gravity model shows the effect on bilateral exports of GDP, distance, GDP per capita, contiguity, landlocked status, speaking a common language, having a common colonizer, and having a similar religion or legal origin; cultural distance is added as an explanatory variable. To determine the causes of cultural distance, cultural distance is regressed on GDP per capita differences, distance, contiguity, speaking a common language, having a common colonizer, being more similar in terms of religion, and having a common legal origin; exports are included a to see whether trade reduces or raises cultural distance.

First, a single-equation estimation is pursued. The trade regressions show that country-pairs that are more culturally distant trade more than otherwise, implying that differences in norms and beliefs, rather than similarities, lead to increased trade; the cultural distance regressions show that, holding constant the other determinants of cultural distance, exports raise rather than lower cultural distance for the average country-pair. 
Because exports and cultural distance are determined simultaneously, the singleequation strategy is likely to be plagued by endogeneity bias; therefore, a simultaneousequations estimation strategy is performed. The results from this estimation show that cultural distance has no impact on exports, but that exports reduce cultural distance. The standard gravity variables, including the cultural and institutional variables that have become commonplace in the literature (such as common colonizer and religious similarity), are sufficient to explain trade flows; differences in the two countries' norms and beliefs do not provide any further explanatory power. Exports prove to be significant in reducing cultural distance, however; the more two countries trade, the lower the disparity between their norms and beliefs will be.

Many of the European Union's policies have been aimed at reducing the barriers between EU countries. Using the World Values Survey as a way of measuring culture, this paper has shown that being part of the EU raises a country-pair's cultural distance. Although EU membership is negatively correlated with cultural distance, this is explained by similar per-capita GDPs and close geographical proximity, not EU membership. However, since trade that is encouraged by the EU's policies of integration has the effect of bringing countries closer together in terms of their norms and beliefs, their cultural distance should fall over time.

In terms of policy implications, if the European Union desires to reduce the differences between member countries, then further reductions in internal barriers to trade would be a means to that end. It is perhaps surprising that there still exist so many differences in the norms and beliefs of individuals throughout the EU, but this research implies that such differences will fade away over time as international trade flows allow for the full integration of production and consumption across Europe.

Received 15 October 2013, Revised 18 August 2014, Accepted 23 April 2015

\section{References}

Bastos, Paulo, and Joana Silva. "Cultural Links, Firm Heterogeneity and the Intensive and Extensive Margins of International Trade." Firm Heterogeneity and the Intensive and Extensive Margins of International Trade (November 1, 2008) (2008). 
Beugelsdijk, Sjoerd. "A note on the theory and measurement of trust in explaining differences in economic growth." Cambridge Journal of Economics 30, no. 3 (2006): 371387.

Chan, Kenneth S. "Trade, social values, and the generalized trust." Southern Economic Journal (2007): 733-753.

Coyne, Christopher J., and Claudia R. Williamson. "Trade openness and cultural creative destruction." Journal of Entrepreneurship and Public Policy 1, no. 1 (2012): 22-49.

De Groot, Henri LF, Gert-Jan Linders, Piet Rietveld, and Uma Subramanian. "The institutional determinants of bilateral trade patterns." Kyklos 57, no. 1 (2004): 103-123.

Disdier, Anne-Célia, and Thierry Mayer. "Je t'aime, moi non plus: Bilateral opinions and international trade." European Journal of Political Economy 23, no. 4 (2007): 1140-1159.

Francois, Joseph F., and Miriam Manchin. "Institutions, infrastructure and trade." Available at SSRN 964209 (2007).

Guiso, Luigi, Paola Sapienza, and Luigi Zingales. "Does culture affect economic outcomes?" Journal of Economic Perspectives 20, no. 2 (2006): 23-48.

Guiso, Luigi, Paola Sapienza, and G. Zingales. "Cultural biases in economic exchange?." Quarterly Journal of Economics 124, no. 3 (2009): 1095-1131.

Guo, Rongxing. "How culture influences foreign trade: evidence from the US and China." The Journal of Socio-Economics 33, no. 6 (2004): 785-812.

Hutchinson, William K. "Linguistic Distance as a Determinant of Bilateral Trade." Southern Economic Journal (2005): 1-15.

Inglehart, Ronald, and Wayne E. Baker. "Modernization, cultural change, and the persistence of traditional values." American Sociological Review (2000): 19-51.

Inglehart, Ronald, Robert Foa, Christopher Peterson, and Christian Welzel. "Development, freedom, and rising happiness." Perspectives on Psychological Science 3, no. 4 (2008): 264-285.

Inglehart, Ronald, and Christian Welzel. Modernization, cultural change, and democracy: The human development sequence. Cambridge University Press, (2005).

Knack, Stephen, and Philip Keefer. "Does social capital have an economic payoff? A cross- 
country investigation.” The Quarterly journal of economics (1997): 1251-1288.

Kónya, István. "Modeling cultural barriers in international trade.” Review of International Economics 14, no. 3 (2006): 494-507.

La Porta, Rafael, Florencio Lopez-de-Silanes, Andrei Shleifer, and Robert Vishny. "Trust in large organizations." American Economic Review 87, no. 2 (1997): 333-338.

La Porta, Rafael, Florencio Lopez-de-Silanes, Andrei Shleifer, and Robert Vishny. "The quality of government." Journal of Law, Economics and Organization 15 (1999): 222-279.

Linders, Gert-Jan, and Henri LF De Groot. "Estimation of the gravity equation in the presence of zero flows." Available at SSRN 924160 (2006).

Melitz, Jacques. "Language and foreign trade." European Economic Review 52, no. 4 (2008): 667-99.

Santos Silva, Joao and Silvana Tenreyro. "The log of gravity." Review of Economics and Statistics 88, no. 4 (2006): 641-58.

Tabellini, Guido. "Culture and institutions: economic development in the regions of Europe." Journal of the European Economic Association 8, no. 4 (2010): 677-716.

Tadesse, Bedassa and Roger White. "Cultural distance as a determinant of bilateral trade flows: Do immigrants counter the effect of cultural differences?" Applied Economics Letters (2008): 1-6.

Westerlund, Joakim, and Fredrik Wilhelmsson. "Estimating the gravity model without gravity using panel data." Applied Economics 43, no. 6 (2011): 641-649.

White, Roger, and Bedassa Tadesse. "Cultural distance and the US immigrant-trade link." The World Economy 31, no. 8 (2008): 1078-1096. 
Table 1. Trust in the European Union

\begin{tabular}{|c|c|c|c|c|c|}
\hline & 1981 1984 & \begin{tabular}{|l|}
$1989 \sim 1993$ \\
\end{tabular} & 1994 1998 & 1999 2004 & $2005 \sim 2008$ \\
\hline Austria & & 28.2 & & 31.3 & \\
\hline Belgium & 25.1 & 30.6 & & 29.4 & \\
\hline Bulgaria & & 28.7 & 23.7 & 24.9 & 19.6 \\
\hline Cyprus & & & & & 9.7 \\
\hline Czech Republic & & 27.4 & 27.2 & 23.4 & \\
\hline Denmark & 45.9 & 55.5 & & 64.1 & \\
\hline Estonia & & 27.6 & 21.1 & 21.7 & \\
\hline Finland & & 59.5 & 47.9 & 56.8 & 58.0 \\
\hline France & 22.3 & 21.4 & & 21.4 & 18.7 \\
\hline Germany & 25.9 & 26.8 & 32.1 & 35.9 & 33.8 \\
\hline Greece & & & & 20.5 & \\
\hline Hungary & 31.9 & 23.8 & 22.5 & 21.4 & \\
\hline Ireland & 40.0 & 46.8 & & 35.2 & \\
\hline Italy & 24.5 & 32.8 & & 31.8 & 27.5 \\
\hline Latvia & & 19.0 & 23.9 & 16.7 & \\
\hline Lithuania & & 30.8 & 21.3 & 23.4 & \\
\hline Luxembourg & & & & 24.9 & \\
\hline Malta & 9.4 & 22.9 & & 20.4 & \\
\hline Netherlands & 38.1 & 50.3 & & 59.4 & 42.6 \\
\hline Poland & & 28.4 & 16.9 & 18.3 & 18.1 \\
\hline Portugal & & 20.7 & & 9.8 & \\
\hline Romania & & 15.8 & 17.9 & 9.9 & 19.3 \\
\hline Slovakia & & 21.3 & 25.8 & 15.2 & \\
\hline Slovenia & & 16.3 & 15.3 & 21.2 & 17.5 \\
\hline Spain & 32.2 & 32.1 & 28.7 & 34.5 & 19.8 \\
\hline Sweden & 52.1 & 59.6 & 56.6 & 63.7 & 65.2 \\
\hline United Kingdom & 42.5 & 42.1 & 30.4 & 28.5 & 30.0 \\
\hline
\end{tabular}

(Note) Trust is the percentage of respondents to the World Values Survey who agree that most people can be trusted. 
Table 2. Respect in the European Union

\begin{tabular}{|c|c|c|c|c|c|}
\hline & 1981 1984 & 1989 1993 & $1994 \sim 1998$ & 1999 2004 & $2005 \sim 2008$ \\
\hline Austria & & 66.6 & & 71.4 & \\
\hline Belgium & 45.3 & 69.5 & & 83.0 & \\
\hline Bulgaria & & 51.5 & 46.4 & 59.3 & 53.8 \\
\hline Cyprus & & & & & 70.6 \\
\hline Czech Republic & & 66.1 & 60.0 & 63.0 & \\
\hline Denmark & 57.8 & 80.9 & & 87.3 & \\
\hline Estonia & & 70.2 & 59.6 & 71.3 & \\
\hline Finland & & 80.3 & 82.5 & 82.7 & 86.9 \\
\hline France & 58.6 & 78.3 & & 85.2 & 86.8 \\
\hline Germany & 42.0 & 75.0 & 88.3 & 72.0 & 75.1 \\
\hline Greece & & & & 52.5 & \\
\hline Hungary & 30.8 & 61.7 & 63.5 & 65.6 & \\
\hline Ireland & 55.6 & 76.4 & & 75.0 & \\
\hline Italy & 43.1 & 66.1 & & 75.0 & 74.4 \\
\hline Latvia & & 69.7 & 72.5 & 69.5 & \\
\hline Lithuania & & 56.7 & 54.1 & 57.6 & \\
\hline Luxembourg & & & & 78.1 & \\
\hline Malta & 24.4 & 41.3 & & 61.0 & \\
\hline Netherlands & 57.1 & 88.1 & & 91.1 & 86.6 \\
\hline Poland & & 76.5 & 81.5 & 80.1 & 84.9 \\
\hline Portugal & & 69.6 & & 65.4 & \\
\hline Romania & & 56.0 & 72.1 & 58.3 & 59.7 \\
\hline Slovakia & & 55.2 & 57.1 & 57.0 & \\
\hline Slovenia & & 74.5 & 72.0 & 70.1 & 75.9 \\
\hline Spain & 44.2 & 73.0 & 75.6 & 79.7 & 72.3 \\
\hline Sweden & 71.1 & 90.8 & 90.4 & 92.5 & 93.6 \\
\hline United Kingdom & 62.1 & 79.2 & 85.9 & 83.0 & 85.3 \\
\hline
\end{tabular}

(Note) Respect is the percentage of respondents to the World Values Survey who say that tolerance and respect for other people is a quality that is important for children to learn at home. 
Table 3. Control in the European Union

\begin{tabular}{|c|c|c|c|c|c|}
\hline & $1981 \sim 1984$ & $1989 \sim 1993$ & 1994 1998 & 1999 2004 & 2005 2008 \\
\hline Austria & & 76 & & 75 & \\
\hline Belgium & 63 & 65 & & 66 & \\
\hline Bulgaria & & 52 & 53 & 62 & 58 \\
\hline Cyprus & & & & & 75 \\
\hline Czech Republic & & 66 & 65 & 69 & \\
\hline Denmark & 70 & 70 & & 73 & \\
\hline Estonia & & 63 & 60 & 60 & \\
\hline Finland & & 76 & 77 & 74 & 75 \\
\hline France & 63 & 62 & & 64 & 67 \\
\hline Germany & 70 & 68 & 69 & 72 & 68 \\
\hline Greece & & & & 70 & \\
\hline Hungary & 68 & 65 & 64 & 62 & \\
\hline Ireland & 69 & 71 & & 73 & \\
\hline Italy & 55 & 64 & & 63 & 63 \\
\hline Latvia & & 64 & 56 & 58 & \\
\hline Lithuania & & 66 & 61 & 63 & \\
\hline Luxembourg & & & & 70 & \\
\hline Malta & 71 & 74 & & 74 & \\
\hline Netherlands & 59 & 62 & & 67 & 67 \\
\hline Poland & & 62 & & 62 & 66 \\
\hline Portugal & & 66 & & 68 & \\
\hline Romania & & 63 & 63 & 67 & 76 \\
\hline Slovakia & & 66 & 64 & 63 & \\
\hline Slovenia & & 64 & 69 & 72 & 75 \\
\hline Spain & 65 & 68 & 63 & 67 & 69 \\
\hline Sweden & 70 & 75 & 73 & 74 & 78 \\
\hline United Kingdom & 67 & 70 & & 72 & 73 \\
\hline
\end{tabular}

(Note) Control is the average response (from 1 to 100) that indicates how much freedom of choice and control in life are felt by the respondents to the World Values Survey. 
Table 4. Obedience in the European Union

\begin{tabular}{|c|c|c|c|c|c|}
\hline & $1981 \sim 1984$ & 1989 1993 & 1994 1998 & 1999 2004 & $2005 \sim 2008$ \\
\hline Austria & & 25.5 & & 16.7 & \\
\hline Belgium & 28.2 & 37.4 & & 42.8 & \\
\hline Bulgaria & & 18.7 & 20.3 & 15.8 & 25.0 \\
\hline Cyprus & & & & & 49.9 \\
\hline Czech Republic & & 20.9 & 14.0 & 17.2 & \\
\hline Denmark & 13.6 & 20.3 & & 14.4 & \\
\hline Estonia & & 18.8 & 27.0 & 28.5 & \\
\hline Finland & & 25.6 & 28.1 & 30.2 & 32.8 \\
\hline France & 17.6 & 53.0 & & 35.6 & 41.2 \\
\hline Germany & 15.5 & 23.9 & 12.3 & 13.7 & 15.9 \\
\hline Greece & & & & 10.8 & \\
\hline Hungary & 30.9 & 44.8 & 30.8 & 33.3 & \\
\hline Ireland & 33.4 & 35.2 & & 47.9 & \\
\hline Italy & 27.3 & 33.8 & & 27.8 & 26.3 \\
\hline Latvia & & 15.3 & 19.4 & 20.4 & \\
\hline Lithuania & & 24.5 & 22.9 & 19.7 & \\
\hline Luxembourg & & & & 26.1 & \\
\hline Malta & 24.0 & 55.5 & & 41.1 & \\
\hline Netherlands & 23.1 & 33.6 & & 25.5 & 40.2 \\
\hline Poland & & 42.0 & 48.7 & 32.5 & 48.8 \\
\hline Portugal & & 45.6 & & 38.8 & \\
\hline Romania & & 19.5 & 13.7 & 18.8 & 17.8 \\
\hline Slovakia & & 35.7 & 26.8 & 26.4 & \\
\hline Slovenia & & 39.8 & 28.2 & 25.1 & 31.7 \\
\hline Spain & 29.7 & 43.0 & 43.8 & 48.7 & 37.2 \\
\hline Sweden & 13.3 & 24.9 & 15.9 & 12.7 & 15.6 \\
\hline United Kingdom & 37.1 & 39.4 & 49.6 & 48.8 & 46.2 \\
\hline
\end{tabular}

(Note) Obedience is the percentage of respondents to the World Values Survey who say that obedience is a quality that is important for children to learn at home. 
Table 5. Summary statistics

\begin{tabular}{|c|c|c|}
\hline & Mean & Standard deviation \\
\hline $\ln \left(\right.$ Exports $\left._{i j}\right)$ & 12.65 & 3.42 \\
\hline Cultural Distance $_{i j}$ & 34.36 & 15.12 \\
\hline$E U$ & 0.15 & 0.36 \\
\hline EU old & 0.030 & 0.17 \\
\hline EUnew & 0.030 & 0.17 \\
\hline EU oldnew & 0.060 & 0.24 \\
\hline Other FTA & 0.35 & 0.48 \\
\hline $\ln \left(G D P_{i}\right)$ & 18.50 & 1.95 \\
\hline $\ln \left(G D P_{j}\right)$ & 18.50 & 1.96 \\
\hline $\ln \left(\right.$ Distance $\left._{i j}\right)$ & 7.95 & 0.96 \\
\hline $\ln \left(G D P_{i} / P O P_{i}\right)$ & 8.54 & 1.44 \\
\hline $\ln \left(G D P_{j} / P O P_{j}\right)$ & 8.50 & 1.45 \\
\hline Common Border ${ }_{i j}$ & 0.045 & 0.21 \\
\hline Landlocked $_{i j}$ & 0.28 & 0.49 \\
\hline Common Language $_{i j}$ & 0.10 & 0.30 \\
\hline Common Colonizer & 0.033 & 0.18 \\
\hline Religious Similarity $_{i j}$ & 0.30 & 0.27 \\
\hline Legal Similarity $_{i j}$ & 0.26 & 0.44 \\
\hline
\end{tabular}


Table 6. The effect of cultural distance on trade

(EU and non-EU trade bloc dummies)

\begin{tabular}{|c|c|c|c|}
\hline & (1) & (2) & (3) \\
\hline$E U$ & $\begin{array}{l}-0.27^{* * *} \\
(0.075)\end{array}$ & $\begin{array}{l}-0.21^{* * *} \\
(0.076)\end{array}$ & $\begin{array}{c}-0.13^{*} \\
(0.072)\end{array}$ \\
\hline Other FTA & $\begin{array}{c}0.26^{* * *} \\
(0.062)\end{array}$ & $\begin{array}{l}0.26^{* * *} \\
(0.061)\end{array}$ & $\begin{array}{c}0.12^{* *} \\
(0.058)\end{array}$ \\
\hline Cultural Distance $_{i j}$ & $\begin{array}{l}-0.0026^{*} \\
(0.0015)\end{array}$ & $\begin{array}{c}-0.0024 \\
(0.0015)\end{array}$ & $\begin{array}{l}0.0039^{* *} \\
(0.0016)\end{array}$ \\
\hline $\ln \left(G D P_{i}\right)$ & $\begin{array}{l}1.25^{* * *} \\
(0.067)\end{array}$ & $\begin{array}{l}1.11^{* * *} \\
(0.079)\end{array}$ & $\begin{array}{l}1.15^{* * *} \\
(0.081)\end{array}$ \\
\hline $\ln \left(G D P_{j}\right)$ & $\begin{array}{l}1.02^{* * *} \\
(0.045)\end{array}$ & $\begin{array}{l}1.33^{* * *} \\
(0.092)\end{array}$ & $\begin{array}{l}1.37^{* * *} \\
(0.095)\end{array}$ \\
\hline $\ln \left(\right.$ Distance $\left._{i j}\right)$ & $\begin{array}{l}-1.67^{* * *} \\
(0.031)\end{array}$ & $\begin{array}{l}-1.58^{* * *} \\
(0.035)\end{array}$ & $\begin{array}{l}-1.45^{* * *} \\
(0.033)\end{array}$ \\
\hline $\ln \left(G D P_{i} / P O P_{i}\right)$ & & $\begin{array}{l}0.24^{* * *} \\
(0.074)\end{array}$ & $\begin{array}{l}0.26^{* * *} \\
(0.072)\end{array}$ \\
\hline $\ln \left(G D P_{j} / P O P_{j}\right)$ & & $\begin{array}{l}-0.30^{* * * *} \\
(0.074)\end{array}$ & $\begin{array}{l}-0.27^{* * *} \\
(0.075)\end{array}$ \\
\hline Common Border ${ }_{i j}$ & & $\begin{array}{l}0.53^{* * *} \\
(0.087)\end{array}$ & $\begin{array}{c}0.20^{* *} \\
(0.080)\end{array}$ \\
\hline Landlocked $_{i j}$ & & $\begin{array}{c}0.33 \\
(0.50)\end{array}$ & $\begin{array}{c}0.73 \\
(0.52)\end{array}$ \\
\hline Common Language $_{i j}$ & & & $\begin{array}{c}0.33^{* * *} \\
(0.065)\end{array}$ \\
\hline Common Colonizer $_{i j}$ & & & $\begin{array}{l}1.59^{* * *} \\
(0.13)\end{array}$ \\
\hline Religious Similarity $_{i j}$ & & & $\begin{array}{c}0.038 \\
(0.064)\end{array}$ \\
\hline Legal Similarity $_{i j}$ & & & $\begin{array}{l}0.52^{* * *} \\
(0.042)\end{array}$ \\
\hline $\mathrm{R}^{2}$ & 0.83 & 0.83 & 0.84 \\
\hline Observations & 9,669 & 9,669 & 9,669 \\
\hline
\end{tabular}

(Notes) (i) The dependent variable is the log of real exports from country $i$ to country $j$.

(ii) Standard errors are in parentheses and are corrected for heteroskedasticity.

(iii) A constant term is included but not reported. All regressions include year fixed effects, exporter-year fixed effects, and importer-year fixed effects.

(iv) * represents $90 \%$ significance, $* *$ represents $95 \%$ significance, and *** represents $99 \%$ significance. 


\section{Table 7. The effect of cultural distance on trade}

(oldest and the newest EU members dummies)

\begin{tabular}{|c|c|c|c|}
\hline & (1) & (2) & (3) \\
\hline EU old & $\begin{array}{l}-1.17^{* * *} \\
(0.087)\end{array}$ & $\begin{array}{l}-1.18^{* * *} \\
(0.089)\end{array}$ & $\begin{array}{l}-1.09^{* * *} \\
(0.085)\end{array}$ \\
\hline EU new & $\begin{array}{c}0.46^{* * *} \\
(0.11)\end{array}$ & $\begin{array}{l}0.49^{* * *} \\
(0.11)\end{array}$ & $\begin{array}{l}0.35^{* * *} \\
(0.10)\end{array}$ \\
\hline EU oldnew & $\begin{array}{l}-0.33^{* * *} \\
(0.069)\end{array}$ & $\begin{array}{l}-0.28^{* * *} \\
(0.069)\end{array}$ & $\begin{array}{c}-0.11^{*} \\
(0.067)\end{array}$ \\
\hline Other FTA & $\begin{array}{l}0.25^{* * *} \\
(0.060)\end{array}$ & $\begin{array}{l}0.25^{* * *} \\
(0.059)\end{array}$ & $\begin{array}{c}0.12^{*} \\
(0.056)\end{array}$ \\
\hline Cultural Distance $_{i j}$ & $\begin{array}{l}-0.0015 \\
(0.0015)\end{array}$ & $\begin{array}{l}-0.0013 \\
(0.0015)\end{array}$ & $\begin{array}{l}0.0046^{* * *} \\
(0.0016)\end{array}$ \\
\hline $\ln \left(G D P_{i}\right)$ & $\begin{array}{l}1.25^{* * * *} \\
(0.067)\end{array}$ & $\begin{array}{l}1.10^{* * * *} \\
(0.078)\end{array}$ & $\begin{array}{l}1.14^{* * * *} \\
(0.081)\end{array}$ \\
\hline $\ln \left(G D P_{j}\right)$ & $\begin{array}{l}1.02^{* * *} \\
(0.046)\end{array}$ & $\begin{array}{l}1.33^{* * *} \\
(0.092)\end{array}$ & $\begin{array}{l}1.37^{* * *} \\
(0.094)\end{array}$ \\
\hline $\ln \left(\right.$ Distance $\left._{i j}\right)$ & $\begin{array}{l}-1.67^{* * *} \\
(0.029)\end{array}$ & $\begin{array}{l}-1.59^{* * *} \\
(0.032)\end{array}$ & $\begin{array}{l}-1.47^{* * *} \\
(0.031)\end{array}$ \\
\hline $\ln \left(G D P_{i} / P O P_{i}\right)$ & & $\begin{array}{l}0.28^{* * * *} \\
(0.073)\end{array}$ & $\begin{array}{l}0.29^{* * * *} \\
(0.072)\end{array}$ \\
\hline $\ln \left(G D P_{j} / P O P_{j}\right)$ & & $\begin{array}{l}-0.27^{* * *} \\
(0.074)\end{array}$ & $\begin{array}{l}-0.24^{* * *} \\
(0.076)\end{array}$ \\
\hline Common Border ${ }_{i j}$ & & $\begin{array}{l}0.57^{* * *} \\
(0.085)\end{array}$ & $\begin{array}{l}0.24^{* * *} \\
(0.077)\end{array}$ \\
\hline Landlocked $_{i j}$ & & $\begin{array}{l}0.46 \\
(0.50)\end{array}$ & $\begin{array}{c}0.84 \\
(0.51)\end{array}$ \\
\hline Common Language $_{i j}$ & & & $\begin{array}{l}0.30^{* * * *} \\
(0.066)\end{array}$ \\
\hline Common Colonizer $_{i j}$ & & & $\begin{array}{l}1.63^{* * *} \\
(0.13)\end{array}$ \\
\hline Religious Similarity $_{i j}$ & & & $\begin{array}{c}0.071 \\
(0.065)\end{array}$ \\
\hline Legal Similarity $_{i j}$ & & & $\begin{array}{l}0.50^{* * *} \\
(0.044)\end{array}$ \\
\hline $\mathrm{R}^{2}$ & 0.83 & 0.83 & 0.84 \\
\hline Observations & 9,669 & 9,669 & 9,669 \\
\hline
\end{tabular}

(Notes) (i) The dependent variable is the log of real exports from country $i$ to country $j$.

(ii) Standard errors are in parentheses and are corrected for heteroskedasticity.

(iii) A constant term is included but not reported. All regressions include year fixed effects, exporter-year fixed effects, and importer-year fixed effects.

(iv) * represents $90 \%$ significance, $* *$ represents $95 \%$ significance, and $* * *$ represents $99 \%$ significance. 
Table 8. The effect of trade on cultural distance

\begin{tabular}{|c|c|c|}
\hline & (1) & (2) \\
\hline$E U$ & $\begin{array}{l}1.98^{* * *} \\
(0.51)\end{array}$ & \\
\hline EU old & & $\begin{array}{l}6.33^{* * *} \\
(0.81)\end{array}$ \\
\hline EU new & & $\begin{array}{c}-3.86^{* * * *} \\
(0.71)\end{array}$ \\
\hline EU oldnew & & $\begin{array}{l}1.51^{* * *} \\
(0.56)\end{array}$ \\
\hline Other FTA & $\begin{array}{l}-0.71^{*} \\
(0.40)\end{array}$ & $\begin{array}{l}-0.69^{*} \\
(0.40)\end{array}$ \\
\hline $\ln \left(\right.$ Exports $\left._{i j}\right)$ & $\begin{array}{l}0.30^{* * *} \\
(0.076)\end{array}$ & $\begin{array}{l}0.36^{* * *} \\
(0.075)\end{array}$ \\
\hline$\left|\ln \left(G D P_{i} / P O P_{i}\right)-\ln \left(G D P_{j} / P O P_{j}\right)\right|$ & $\begin{array}{l}2.76^{* * *} \\
(0.14)\end{array}$ & $\begin{array}{l}2.83^{* * * *} \\
(0.14)\end{array}$ \\
\hline $\ln \left(\right.$ Distance $\left._{i j}\right)$ & $\begin{array}{l}3.62^{* * *} \\
(0.27)\end{array}$ & $\begin{array}{l}3.55^{* * *} \\
(0.26)\end{array}$ \\
\hline Common Border ${ }_{i j}$ & $\begin{array}{l}1.47^{* *} \\
(0.64)\end{array}$ & $\begin{array}{c}1.13^{*} \\
(0.65)\end{array}$ \\
\hline Common Language $_{i j}$ & $\begin{array}{c}-1.10^{* *} \\
(0.47)\end{array}$ & $\begin{array}{c}-1.04^{* *} \\
(0.48)\end{array}$ \\
\hline Common Colonizer $_{i j}$ & $\begin{array}{c}-3.67^{* * *} \\
(0.71)\end{array}$ & $\begin{array}{c}-4.04^{* * * *} \\
(0.72)\end{array}$ \\
\hline Religious Similarity $_{i j}$ & $\begin{array}{c}-3.46^{* * * *} \\
(0.47)\end{array}$ & $\begin{array}{c}-3.70^{* * * *} \\
(0.48)\end{array}$ \\
\hline Legal Similarity $_{i j}$ & $\begin{array}{c}-2.95^{* * *} \\
(0.31)\end{array}$ & $\begin{array}{c}-2.63^{* * *} \\
(0.31)\end{array}$ \\
\hline $\mathrm{R}^{2}$ & 0.61 & 0.61 \\
\hline Observations & 8,887 & 8,887 \\
\hline
\end{tabular}

(Notes) (i) The dependent variable is cultural distance between country $i$ and country $j$.

(ii) Column 1 includes a dummy variable equal to 1 if both countries are members of the EU; Column 2 includes dummy variables representing the oldest and newest members of the EU.

(iii) Standard errors are in parentheses and are corrected for heteroskedasticity.

(iv) A constant term is included but not reported. All regressions include year fixed effects, exporter-year fixed effects, and importer-year fixed effects.

(v) * represents 90\% significance, $* *$ represents $95 \%$ significance, and $* * *$ represents $99 \%$ significance. 


\section{Table 9. Simultaneous equations}

(EU and non-EU trade bloc dummies)

\begin{tabular}{|c|c|c|}
\hline & Trade & Cultural Distance \\
\hline$E U$ & $\begin{array}{l}-0.13^{*} \\
(0.072)\end{array}$ & $\begin{array}{l}1.93^{* * *} \\
(0.51)\end{array}$ \\
\hline Other FTA & $\begin{array}{l}0.13^{* *} \\
(0.050)\end{array}$ & $\begin{array}{l}0.0044 \\
(0.35)\end{array}$ \\
\hline Cultural Distance $_{i j}$ & $\begin{array}{l}0.0058 \\
(0.0052)\end{array}$ & \\
\hline $\ln \left(\right.$ Exports $\left._{i j}\right)$ & & $\begin{array}{c}-0.36^{* * *} \\
(0.12)\end{array}$ \\
\hline $\ln \left(G D P_{i}\right)$ & $\begin{array}{l}1.04^{* * *} \\
(0.050)\end{array}$ & \\
\hline $\ln \left(G D P_{j}\right)$ & $\begin{array}{l}0.63^{* * *} \\
(0.052)\end{array}$ & \\
\hline$\left|\ln \left(G D P_{i} / P O P_{i}\right)-\ln \left(G D P_{j} / P O P_{j}\right)\right|$ & & $\begin{array}{l}2.87^{* * *} \\
(0.10)\end{array}$ \\
\hline $\ln \left(\right.$ Distance $\left._{i j}\right)$ & $\begin{array}{l}-1.46^{* * * *} \\
(0.035)\end{array}$ & $\begin{array}{l}2.60^{* * * * *} \\
(0.19)\end{array}$ \\
\hline $\ln \left(G D P_{i} / P O P_{i}\right)$ & $\begin{array}{l}-0.20^{* * *} \\
(0.062)\end{array}$ & \\
\hline $\ln \left(G D P_{j} / P O P_{j}\right)$ & $\begin{array}{l}-0.28^{* * *} \\
(0.068)\end{array}$ & \\
\hline Common Border ${ }_{i j}$ & $\begin{array}{l}0.19^{* *} \\
(0.080)\end{array}$ & $\begin{array}{l}1.38^{* *} \\
(0.57)\end{array}$ \\
\hline Landlocked $_{i j}$ & $\begin{array}{c}-3.67^{* * *} \\
(0.30)\end{array}$ & \\
\hline Common Language $_{i j}$ & $\begin{array}{l}0.34^{* * *} \\
(0.061)\end{array}$ & $\begin{array}{l}-1.02^{* *} \\
(0.43)\end{array}$ \\
\hline Common Colonizer $_{i j}$ & $\begin{array}{l}1.60^{* * *} \\
(0.097)\end{array}$ & $\begin{array}{l}-2.63^{* * *} \\
(0.68)\end{array}$ \\
\hline Religious Similarity $_{i j}$ & $\begin{array}{l}0.048 \\
(0.066)\end{array}$ & $\begin{array}{c}-3.52^{* * * *} \\
(0.42)\end{array}$ \\
\hline Legal Similarity $_{i j}$ & $\begin{array}{l}0.53^{* * *} \\
(0.042)\end{array}$ & $\begin{array}{c}-2.44^{* * *} \\
(0.28)\end{array}$ \\
\hline $\mathrm{R}^{2}$ & 0.84 & 0.61 \\
\hline Observations & 9,669 & 9,669 \\
\hline
\end{tabular}

(Notes) (i) The dependent variable is the $\log$ of real exports from country $i$ to country $j$ in Column 1 , and cultural distance between country $i$ and country $j$ in Column 2 .

(ii) Standard errors are in parentheses and are corrected for heteroskedasticity.

(iii) A constant term is included but not reported. All regressions include year fixed effects, exporter-year fixed effects, and importer-year fixed effects.

(iv) * represents $90 \%$ significance, $* *$ represents $95 \%$ significance, and $* * *$ represents $99 \%$ significance. 
Table 10. Simultaneous equations

(oldest and the newest EU members' dummies)

\begin{tabular}{|c|c|c|}
\hline & Trade & Cultural Distance \\
\hline EU old & $\begin{array}{c}-1.07^{* * *} \\
(0.11)\end{array}$ & $\begin{array}{l}5.78^{* * * *} \\
(0.81)\end{array}$ \\
\hline EU new & $\begin{array}{l}0.32^{* * *} \\
(0.11)\end{array}$ & $\begin{array}{c}-3.61^{* * * *} \\
(0.78)\end{array}$ \\
\hline EU oldnew & $\begin{array}{c}-0.11 \\
(0.082)\end{array}$ & $\begin{array}{l}1.28^{* * *} \\
(0.57)\end{array}$ \\
\hline Other FTA & $\begin{array}{l}0.096^{* *} \\
(0.049)\end{array}$ & $\begin{array}{l}-0.18 \\
(0.34)\end{array}$ \\
\hline Cultural Distance $_{i j}$ & $\begin{array}{c}-0.0016 \\
(0.0051)\end{array}$ & \\
\hline $\ln \left(\right.$ Exports $\left._{i j}\right)$ & & $\begin{array}{l}-0.29^{* *} \\
(0.11)\end{array}$ \\
\hline $\ln \left(G D P_{i}\right)$ & $\begin{array}{l}1.04^{* * *} \\
(0.048)\end{array}$ & \\
\hline $\ln \left(G D P_{j}\right)$ & $\begin{array}{l}0.61^{* * *} \\
(0.052)\end{array}$ & \\
\hline$\left|\ln \left(G D P_{i} / P O P_{i}\right)-\ln \left(G D P_{j} / P O P_{j}\right)\right|$ & & $\begin{array}{l}2.92^{* * *} \\
(0.10)\end{array}$ \\
\hline $\ln \left(\right.$ Distance $\left._{i j}\right)$ & $\begin{array}{l}-1.45^{* * *} \\
(0.034)\end{array}$ & $\begin{array}{l}2.50^{* * *} \\
(0.19)\end{array}$ \\
\hline $\ln \left(G D P_{i} / P O P_{i}\right)$ & $\begin{array}{l}-0.19^{* * *} \\
(0.061)\end{array}$ & \\
\hline $\ln \left(G D P_{j} / P O P_{j}\right)$ & $\begin{array}{l}-0.27^{* * *} \\
(0.068)\end{array}$ & \\
\hline Common Border ${ }_{i j}$ & $\begin{array}{l}0.25^{* * *} \\
(0.080)\end{array}$ & $\begin{array}{l}1.02^{*} \\
(0.57)\end{array}$ \\
\hline Landlocked $_{i j}$ & $\begin{array}{c}-3.75^{* * *} \\
(0.30)\end{array}$ & \\
\hline Common Language $_{i j}$ & $\begin{array}{l}0.30^{* * *} \\
(0.061)\end{array}$ & $\begin{array}{c}-1.01^{* *} \\
(0.43)\end{array}$ \\
\hline Common Colonizer $_{i j}$ & $\begin{array}{l}1.59^{* * *} \\
(0.097)\end{array}$ & $\begin{array}{c}-2.95^{* * *} \\
(0.68)\end{array}$ \\
\hline Religious Similarity $_{i j}$ & $\begin{array}{c}0.048 \\
(0.067)\end{array}$ & $\begin{array}{c}-3.77^{* * *} \\
(0.42)\end{array}$ \\
\hline
\end{tabular}




\section{Table 10. Simultaneous equations}

(oldest and the newest EU members)

(Continued)

\begin{tabular}{|l|c|c|}
\hline & Trade & Cultural Distance \\
\hline Legal Similarity $_{i j}$ & $\begin{array}{c}0.48^{* * *} \\
(0.042)\end{array}$ & $\begin{array}{c}-2.12^{* * *} \\
(0.29)\end{array}$ \\
\hline $\mathrm{R}^{2}$ & 0.84 & 0.61 \\
\hline Observations & 9,669 & 9,669 \\
\hline
\end{tabular}

(Notes) (i) The dependent variable is the $\log$ of real exports from country $i$ to country $j$ in Column 1 , and cultural distance between country $i$ and country $j$ in Column 2 .

(ii) Standard errors are in parentheses and are corrected for heteroskedasticity.

(iii) A constant term is included but not reported. All regressions include year fixed effects, exporter-year fixed effects, and importer-year fixed effects.

(iv) * represents $90 \%$ significance, $* *$ represents $95 \%$ significance, and $* * *$ represents $99 \%$ significance. 


\section{Appendices}

\section{Appendix 1: Data sources}

The cultural distance data (comprising the trust, control, respect, and obedience variables) are from the World Values Survey (www.worldvaluessurvey.org).

Export data are from the IMF's Direction of Trade Statistics; data prior to the year 2000 were obtained from Andy Rose (http://faculty.haas.berkeley.edu/arose/).

GDP and population data are from the World Bank's World Development Indicators.

Distance is calculated using the great-circle method and was obtained from Andy Rose (http://faculty.haas.berkeley.edu/arose/).

The dummy variables representing membership in a trade agreement, contiguity, landlocked status, common language, and common colonizer were obtained from Andy Rose (http://faculty.haas.berkeley.edu/arose/).

The religious similarity variable was calculated from data found in La Porta et al. (1999).

The legal similarity variable was constructed from data found in La Porta et al. (1999). 


\section{Appendix 2: Countries included}

\begin{tabular}{|c|c|c|}
\hline Albania & Germany & Pakistan \\
\hline Algeria & Ghana & Peru \\
\hline Argentina & Greece & Philippines \\
\hline Armenia & Hong Kong & Poland \\
\hline Australia & Hungary & Portugal \\
\hline Austria & Iceland & Romania \\
\hline Azerbaijan & India & Russia \\
\hline Bangladesh & Indonesia & Rwanda \\
\hline Belarus & Iran & Saudi Arabia \\
\hline Belgium & Iraq & Singapore \\
\hline Bosnia and Herzegovina & Ireland & Slovakia \\
\hline Brazil & Israel & Slovenia \\
\hline Bulgaria & Italy & South Africa \\
\hline Burkina Faso & Japan & South Korea \\
\hline Canada & Jordan & Spain \\
\hline Chile & Kyrgyzstan & Sweden \\
\hline China & Latvia & Switzerland \\
\hline Colombia & Lithuania & Tanzania \\
\hline Croatia & Luxembourg & Thailand \\
\hline Cyprus & Macedonia & Trinidad and Tobago \\
\hline Czech Republic & Malaysia & Turkey \\
\hline Denmark & Mali & Uganda \\
\hline Dominican Republic & Malta & Ukraine \\
\hline Egypt & Mexico & United Kingdom \\
\hline El Salvador & Moldova & United States \\
\hline Estonia & Morocco & Uruguay \\
\hline Ethiopia & Netherlands & Venezuela \\
\hline Finland & New Zealand & Vietnam \\
\hline France & Nigeria & Zambia \\
\hline Georgia & Norway & Zimbabwe \\
\hline
\end{tabular}




\section{Appendix 3: Heckman sample selection correction}

\begin{tabular}{|l|c|c|c|}
\hline & OLS & Heckman: selection & Heckman: regression \\
\hline $\ln \left(G D P_{i}\right)$ & $\begin{array}{c}1.19^{* * *} \\
(0.010)\end{array}$ & $\begin{array}{c}0.45^{* * *} \\
(0.025)\end{array}$ & $\begin{array}{c}1.11^{* * *} \\
(0.021)\end{array}$ \\
\hline $\ln \left(G D P_{j}\right)$ & $\begin{array}{c}0.97^{* * *} \\
(0.0094)\end{array}$ & $\begin{array}{c}0.32^{* * *} \\
(0.023)\end{array}$ & $\begin{array}{c}0.92^{* * *} \\
(0.019)\end{array}$ \\
\hline $\ln \left(\right.$ Distance $\left._{i j}\right)$ & $\begin{array}{c}-1.43^{* * *} \\
(0.019)\end{array}$ & $\begin{array}{c}-0.52^{* * *} \\
(0.050)\end{array}$ & $\begin{array}{c}-1.35^{* * *} \\
(0.036)\end{array}$ \\
\hline $\mathrm{R}^{2}$ & 0.74 & \multicolumn{2}{|c|}{9,910} \\
\hline Observations & 9,669 & $4879.65^{* * *}$ \\
\hline Censored observations & & $-3.05^{* * *}$ \\
\hline Wald $\chi^{2}$ Statistic & & \multicolumn{2}{|c|}{} \\
\hline Inverse Mills ratio $(\lambda)$ & & \multicolumn{2}{|c|}{-241} \\
\hline
\end{tabular}

(Notes) (i) The dependent variable is the log of real exports from country $i$ to country $j$.

(ii) Standard errors are in parentheses.

(iii) A constant term is included but not reported. All regressions include year fixed effects.

(iv) * represents $90 \%$ significance, $* *$ represents $95 \%$ significance, and *** represents $99 \%$ significance. 